\title{
Survival of Hendra Virus in the Environment: Modelling the Effect of Temperature
}

\author{
J. C. Scanlan, ${ }^{1}$ N. Y. Kung, ${ }^{2}$ P. W. Selleck, ${ }^{3}$ and H. E. Field ${ }^{2,4}$ \\ ${ }^{1}$ Biosecurity Queensland, Department of Agriculture, Fisheries and Forestry, P.O. Box 102, Toowoomba, QLD 4350, Australia \\ ${ }^{2}$ Biosecurity Queensland, Department of Agriculture, Fisheries and Forestry, GPO Box 46, Brisbane, QLD 4001, Australia \\ ${ }^{3}$ CSIRO Australian Animal Health Laboratory, Private Bag 24, Geelong, VIC 3220, Australia \\ ${ }^{4}$ EcoHealth Alliance, 460 West 34th Street, New York, NY 10001
}

\begin{abstract}
Hendra virus $(\mathrm{HeV})$, a highly pathogenic zoonotic paramyxovirus recently emerged from bats, is a major concern to the horse industry in Australia. Previous research has shown that higher temperatures led to lower virus survival rates in the laboratory. We develop a model of survival of $\mathrm{HeV}$ in the environment as influenced by temperature. We used 20 years of daily temperature at six locations spanning the geographic range of reported $\mathrm{HeV}$ incidents to simulate the temporal and spatial impacts of temperature on $\mathrm{HeV}$ survival. At any location, simulated virus survival was greater in winter than in summer, and in any month of the year, survival was higher in higher latitudes. At any location, year-to-year variation in virus survival $24 \mathrm{~h}$ postexcretion was substantial and was as large as the difference between locations. Survival was higher in microhabitats with lower than ambient temperature, and when environmental exposure was shorter. The within-year pattern of virus survival mirrored the cumulative within-year occurrence of reported $\mathrm{HeV}$ cases, although there were no overall differences in survival in $\mathrm{HeV}$ case years and non-case years. The model examines the effect of temperature in isolation; actual virus survivability will reflect the effect of additional environmental factors.
\end{abstract}

Keywords: Simulation model, Virus survival, Hendra virus

\section{INTRODUCTION}

Hendra virus $(\mathrm{HeV})$ was first described in September 1994, associated with an outbreak of novel acute respiratory disease in horses in a training stable in Brisbane, Australia (Murray et al. 1995; Baldock et al. 1996). It resulted in the deaths of 14 horses and their trainer, and caused a febrile illness in a second stable worker (Selvey et al. 1995). To date, 90 horses and seven people are confirmed or suspected to have been infected with $\mathrm{HeV}$ in 48 reported

Published online: March 19, 2014

Correspondence to: J. C. Scanlan, e-mail: joe.scanlan@daff.qld.gov.au incidents (http://www.daff.qld.gov.au/animal-industries/an imal-health-and-diseases/a-z-list/hendra-virus/generalinformation/what-is-hendra-virus, accessed 4 December 2013). Fruit-bats of the genus Pteropus (commonly known as flying-foxes) are the natural host of the virus (Halpin et al. 2000; Field 2005). While the incidence of infection is low in both horses and humans, the high case fatality rate ( $\sim 80 \%$ in horses, $\sim 60 \%$ in humans) (Field et al. 2010 ; Playford et al. 2010) engenders a high level of concern in horse-owners and trainers, veterinarians, para-veterinary professionals and the general public. All human cases have been associated with close contact with infected horses (Playford et al. 2010), so minimising the risk of infection in 
humans is predicated on minimising infection in horses. Horses are putatively infected following mucosal contact with infectious flying-fox excreta or body fluids (Field et al. 2000; Halpin et al. 2000). While a vaccine for horses has recently become available (http://www.qldhorsecouncil. com/Hendra-Virus/Hendra-Vaccine.aspx, accessed $4 \mathrm{Au}-$ gust 2013), uptake has been limited, with a little over a quarter of the estimated horse population at risk in eastern Australia having been vaccinated to 30 October 2013, notwithstanding encouragement from government, the veterinary profession and the horse industry. (Kung et al. 2013; http://www.queenslandcountrylife.com.au/news/agri culture/general/news/hendra-vaccine-hits-150k/2676692. aspx, accessed 4 December 2013). Thus, emphasis remains on reducing horse exposure to infection.

Flying-foxes can excrete virus at any time of year, and while equine cases have been recorded in most months, the majority occur from June to August (the Australian winter), suggesting that certain ecological and/or environmental factors might contribute to a greater risk of infection at this time (Field et al. 2011).

A previous experimental study exploring $\mathrm{HeV}$ survival in the laboratory environment found that viral load decreased more rapidly with desiccation, at lower $\mathrm{pH}$, in urine rather than in fruit and at higher temperatures (Fogarty et al. 2008). We used data from this previous study and from our own laboratory study to develop a simulation model of the effect of temperature on $\mathrm{HeV}$ survival in the environment. We used the model to explore implications of relative $\mathrm{HeV}$ infection risk under a number of practical scenarios-specifically, at different latitudes, in different years, at different times of year and in different microclimates. Additional environmental factors undoubtedly influence $\mathrm{HeV}$ survival in the environment, but a lack of empirical data precluded their inclusion in the model.

\section{MetHOdS}

\section{The Laboratory Study}

$\mathrm{HeV}$ was cultured in Vero cells from lung tissue collected from infected horses on the original case property (in the Brisbane suburb of Hendra) during the first recorded outbreak in 1994. Vero cells were grown to $100 \%$ confluency in Earles Minimum Essential Medium pH 7.2 (EMEM) supplemented with 5\% foetal calf serum (FCS).
Virus inoculum was diluted in EMEM supplemented with $1 \%$ FCS; $5 \mathrm{~mL}$ was added to each $150 \mathrm{~cm}^{3}$ flask of cells and the flask was incubated at $37^{\circ} \mathrm{C}$ for $1 \mathrm{~h}$. After incubation, the inoculum was discarded and the remaining inoculum washed off with EMEM. Fifty millilitres of EMEM supplemented with $1 \%$ FCS was added to each flask and the flasks incubated at $37^{\circ} \mathrm{C}$. When the cytopathogenic effect neared $100 \%$, the tissue culture supernatant (TCSN) was poured off, clarified by centrifugation at $10,000 \times g$ for $10 \mathrm{~min}$ and stored in $0.5 \mathrm{~mL}$ volumes in sterile tubes. Eight tubes were titrated in Vero cells prior to treatment. Briefly, tenfold dilutions from $10^{-1}$ to $10^{-8}$ of each TCSN were made in EMEM without FCS. Then, $50 \mu \mathrm{L}$ of each dilution was added to ten wells of a flat-bottomed microtitre plates (Nunc), followed by $50 \mu \mathrm{L}$ of EMEM without FCS and $100 \mu \mathrm{L}$ of Vero cells in EMEM with 10\% FCS. The plates were incubated at $37^{\circ} \mathrm{C}$ for 3 days and the presence or absence of cytopathic effect in each well recorded. The titre in $\mathrm{TCID}_{50} / \mathrm{mL}$ in each tube was calculated by the method of Reed and Muench (1938).

Thirty tubes were placed at each of three temperatures $-56^{\circ} \mathrm{C}, 22^{\circ} \mathrm{C}$ (room temperature) and $4^{\circ} \mathrm{C}$. At specific times, two tubes were removed and the $\mathrm{HeV}$ titrated in Vero cells. The removal times for tubes stored at $56^{\circ} \mathrm{C}$ were at 10 -min intervals starting at $10 \mathrm{~min}$ post-treatment while the removal times for the tubes stored at 22 and $4^{\circ} \mathrm{C}$ were at weekly intervals starting from 1 week post-treatment. At the time of removal, the residual virus in each tube was titrated in Vero cells in sterile, flat-bottomed microtitre plates as described above. All work was done at the CSIRO Australian Animal Health Laboratories, Geelong, Australia under Physical Containment Level 4 conditions.

An exponential decay model was fitted to the first five data points for each temperature and explained 94, 93 and $81 \%$ of the variation for 56,22 and $4^{\circ} \mathrm{C}$, respectively (Fig. 1). The half-life at each temperature was calculated from the regression-1.85, 50.2 and $308 \mathrm{~h}$ for 56,22 and $4^{\circ} \mathrm{C}$.

\section{The Model}

Our model was constructed using STELLA software Version 9.1.4 (http://www.iseesystems.com/). The model simulated the amount of $\mathrm{HeV}$ surviving at hourly intervals over 4 days with the rate of loss being a function of temperature based on our own laboratory work and on published information (Fogarty et al. 2008). The effect of temperature was obtained from a regression of half-life 

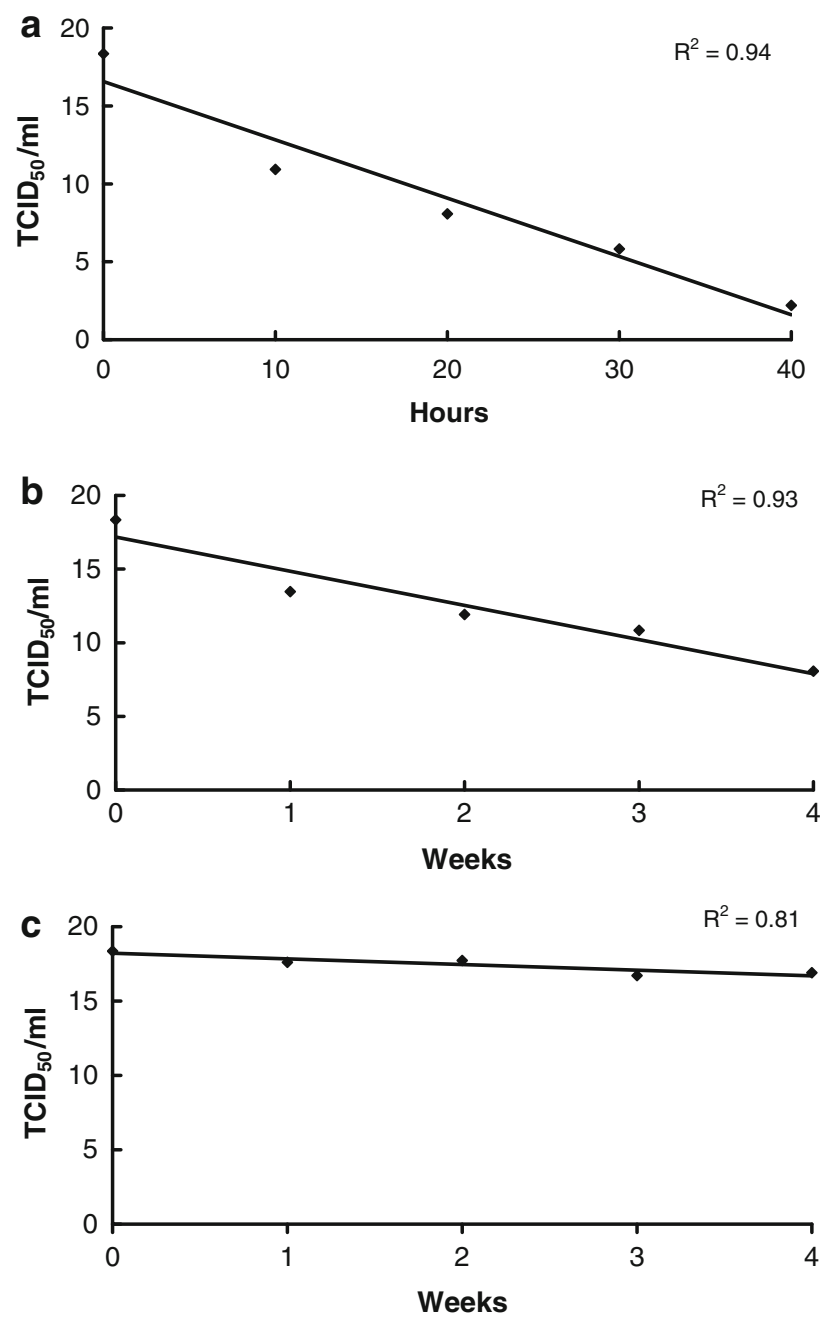

Figure 1. The change in Hendra virus titre over time at $\mathbf{a} 56^{\circ} \mathrm{C}, \mathbf{b} 22^{\circ} \mathrm{C}$ and $\mathbf{c} 4{ }^{\circ} \mathrm{C}$ (note the $\log _{\mathrm{e}}$ scale for $Y$-axis and the different time intervals for the highest temperature).

against temperature (Fig. 2). The half-life at each hour over the 4 days was calculated from the polynomial regression line in Figure 2 by randomly choosing a normally distributed value within the $95 \%$ prediction interval around the regression line for the estimated temperature at that hour. The breakdown rate for each hour was calculated from these half-life values.

The temperature change through the day was estimated from maximum and minimum temperatures (Table 1) obtained from the SILO database (http://www. longpaddock.qld.gov.au/silo/, accessed 19 November 2013) for each location (below) for 1993 to 2012. We used data from the first 4 days of each month for simulations. The change in temperature was simulated as a cosine wave with the minimum temperature being at 3 a.m. and the

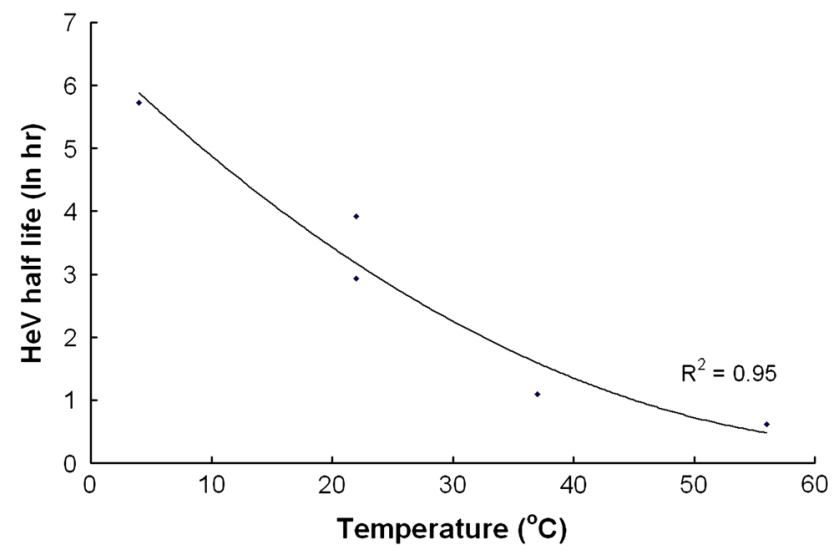

Figure 2. Half-life (h) of Hendra virus at a range of temperatures in the laboratory (derived from data in Fogarty et al. (2008) and laboratory analyses here-see Fig. 1) (note the $\log _{\mathrm{e}}$ scale for $Y$-axis) 
Table 1. Mean maximum and mean minimum temperatures for first 4 days of each month for six locations at which survival of Hendra virus was simulated.

\begin{tabular}{|c|c|c|c|c|c|c|c|c|c|c|c|c|}
\hline \multirow[t]{2}{*}{ Month } & \multicolumn{2}{|c|}{ Cairns } & \multicolumn{2}{|c|}{ Townsville } & \multicolumn{2}{|c|}{ Mackay } & \multicolumn{2}{|c|}{ Rockhampton } & \multicolumn{2}{|c|}{ Murwillumbah } & \multicolumn{2}{|c|}{ Kempsey } \\
\hline & Max & Min & Max & Min & Max & Min & Max & Min & Max & Min & Max & Min \\
\hline January & 31.5 & 23.9 & 31.7 & 24.5 & 30.2 & 23.9 & 32.3 & 22.5 & 29.5 & 20.0 & 26.3 & 18.6 \\
\hline February & 31.2 & 24.1 & 31.4 & 24.6 & 30.8 & 24.3 & 31.8 & 22.6 & 29.1 & 19.9 & 26.3 & 18.7 \\
\hline March & 30.7 & 23.3 & 31.3 & 23.4 & 29.5 & 23.4 & 31.2 & 21.1 & 28.0 & 18.4 & 25.5 & 17.4 \\
\hline April & 29.5 & 21.9 & 30.2 & 20.9 & 28.1 & 21.1 & 29.2 & 18.4 & 25.9 & 15.8 & 23.5 & 14.7 \\
\hline May & 27.9 & 19.9 & 28.1 & 17.6 & 25.7 & 19.1 & 26.5 & 14.4 & 23.5 & 12.5 & 20.8 & 11.4 \\
\hline June & 26.5 & 18.4 & 26.1 & 15.2 & 23.0 & 15.8 & 24.0 & 11.8 & 21.2 & 10.2 & 18.5 & 9.6 \\
\hline July & 26.1 & 17.1 & 25.6 & 13.8 & 22.0 & 13.2 & 23.7 & 10.4 & 21.1 & 9.0 & 17.9 & 8.3 \\
\hline August & 26.8 & 17.3 & 26.3 & 14.6 & 21.8 & 12.6 & 25.1 & 11.4 & 22.6 & 9.2 & 19.2 & 8.8 \\
\hline September & 28.6 & 18.8 & 28.2 & 17.8 & 24.1 & 17.5 & 28.0 & 14.5 & 25.3 & 12.1 & 21.1 & 10.6 \\
\hline October & 29.9 & 20.9 & 29.8 & 21.1 & 26.9 & 19.1 & 29.9 & 17.6 & 26.5 & 14.5 & 22.7 & 13.3 \\
\hline November & 30.9 & 22.5 & 30.9 & 23.1 & 28.8 & 21.2 & 31.2 & 19.8 & 27.6 & 17.1 & 24.3 & 15.6 \\
\hline December & 31.5 & 23.7 & 31.7 & 24.5 & 30.5 & 22.2 & 32.2 & 21.6 & 28.8 & 18.8 & 25.5 & 17.4 \\
\hline
\end{tabular}

maximum at 3 p.m. At each hour, the breakdown rate for that temperature was applied. It is acknowledged that on particular days, the minimum and maximum temperatures may occur at times that differ from this and that there may be departures from a cosine wave during any particular day. However, this simplification is unlikely to alter our results in any meaningful manner. Data on hourly temperature are not readily available for the span of years, nor for the six $\mathrm{HeV}$ incident locations which we used in our model (Cairns, Townsville, Mackay, Rockhampton (all Queensland), Murwillumbah and Kempsey, New South Wales-Fig. 3). The locations span the latitudinal range of reported $\mathrm{HeV}$ incidents, and cover the range of temperatures likely to be experienced by $\mathrm{HeV}$ excreted into the environment.

Within the model, we assumed virus was initially excreted at the coolest time of the night (i.e. 3 a.m.), except in the third experiment where we examined the effect of specified excretion times.

\section{The Simulations}

A series of simulations (below) examined different aspects of the influence of temperature on $\mathrm{HeV}$ survival. Virus survival at $24 \mathrm{~h}$ after initial excretion was used as the measure to compare the effect of location, year, season and microclimate.

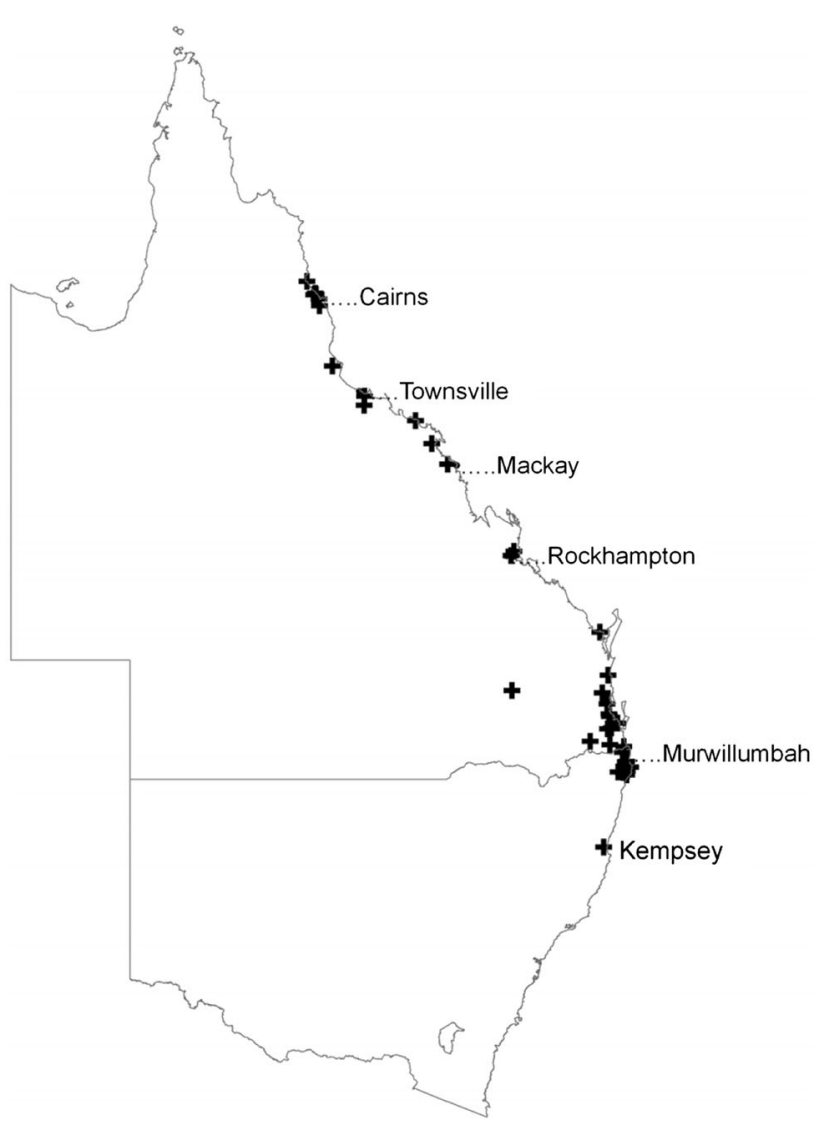

Figure 3. Sites of reported Hendra virus incidents in Queensland and New South Wales and the six locations used for simulations. 
(1) The overall effect of location was examined by using long-term means for maximum and minimum temperatures for the first 4 days of each month of the year at each location (Table 1). Additionally, the simulated mean virus survival rates for each month at each location were compared with the cumulative monthly occurrence of equine $\mathrm{HeV}$ cases (current till end of November 2013).

(2) At each location, simulated virus survival was estimated for each season for 1993-2012 (using January, April, July and October to represent summer, autumn, winter and spring mid-points, respectively). This provided an indication of the inter-year variation for the same month of year.

(3) We then examined relative virus survival to midday following initial excretion at five preceding timepoints over a 12 -h period -6 p.m. on previous day, 9 p.m., at midnight, 3 a.m. and at 6 a.m. This was done for summer (January) and for winter (July) at Rockhampton (other locations gave similar patterns of results, but with different magnitudes—data not shown).

(4) To examine possible microclimatic effects, we lowered the maximum temperature by $1,2,3,4$ and $5^{\circ} \mathrm{C}$ to determine the effect on $\mathrm{HeV}$ survival at $24 \mathrm{~h}$. This was done for summer and winter at Rockhampton.

(5) We compared mean monthly survival for Hendra case years and non-case years for all locations to determine if there were any consistent differences between $\mathrm{HeV}$ survival in years when equine cases were reported $(1994,1995,1999,2004,2006-2013)$ and in years when no equine cases were reported.

\section{Results}

Simulated survival of $\mathrm{HeV}$ in the environment varies substantially between locations (for the same month) and between seasons (for the same location) (Fig. 4). We chose virus survival at $24 \mathrm{~h}$ after initial excretion as a logical comparative measure, but other durations would have given qualitatively similar results. With location, there is a trend of increasing virus survival from north to south, paralleling the decreasing mean temperature gradient ( $\mathrm{Ta}-$ ble 1). In Cairns in summer, the mean survival is $9 \%$ after $24 \mathrm{~h}$, whereas survival is $71 \%$ for winter in Kempsey. For season, there is a similar pattern of virus survival at each location, being highest in winter (July), generally followed by spring (October) and autumn (April), and lowest in summer (January).

The general pattern in $\mathrm{HeV}$ survival shows a decline over the 4-day simulation period, with the rate of decline being most rapid in summer and least in winter, as illustrated by the Rockhampton data (Fig. 5a). Other months showed intermediate patterns of decline (data not shown). The ranking of the locations in terms of $\mathrm{HeV}$ survival remains the same over the 4-day simulation period (Fig. 5b). After 4 days, the highest survival was $29 \%$ in July (the month with the highest overall survival) for Kempsey (the location furthest south).

The variation in survival of $\mathrm{HeV}$ at a particular location over the 20-year simulation period was quite marked (Table 2). In general, the largest variation in survival was in July, with all locations showing at least 30\% difference

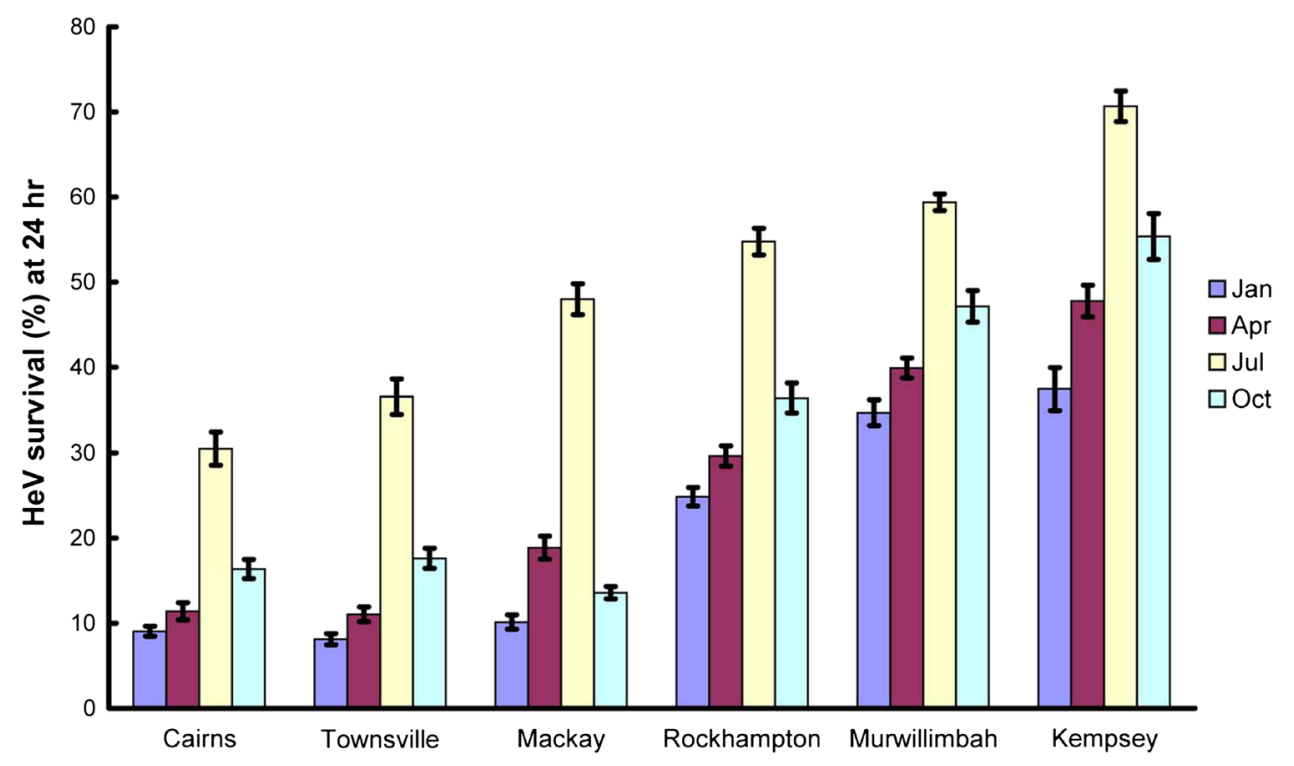

Figure 4. Mean survival of Hendra virus at $24 \mathrm{~h}$ after excretion for six locations and for four seasons. Vertical bars show the standard errors when actual temperatures over the last 20 years are used. 

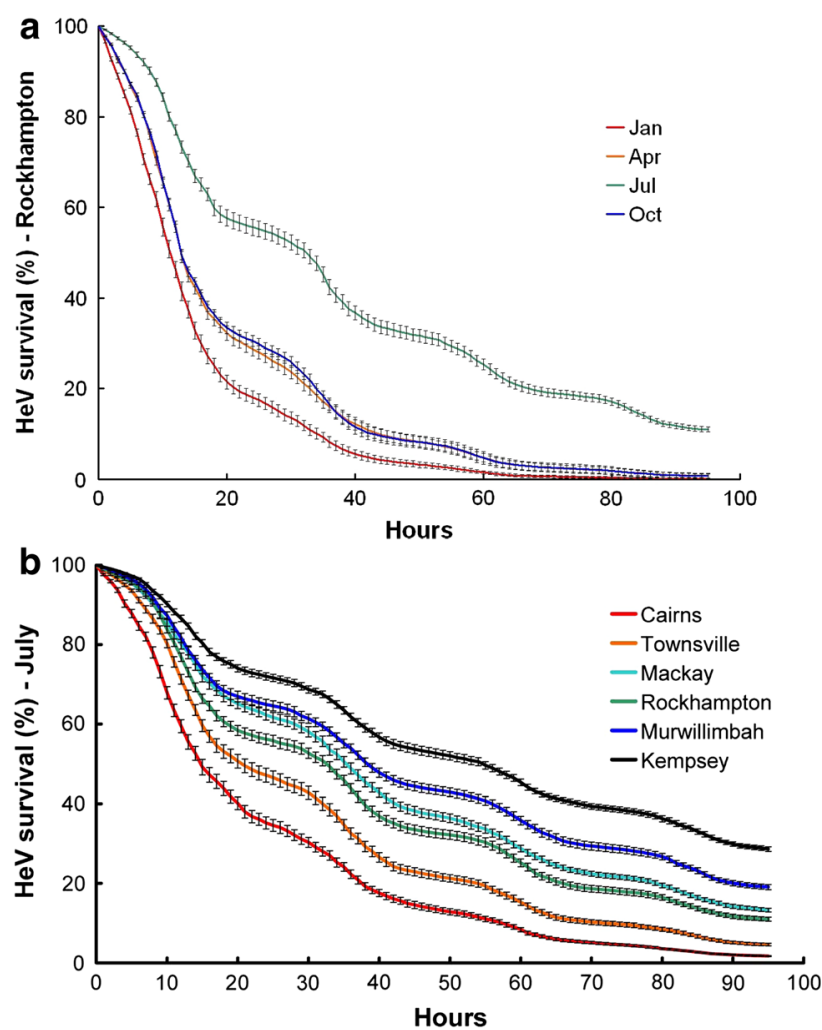

Figure 5. Pattern of Hendra virus survival over a 4-day period after excretion showing the mean for 1993-2012 simulated for a each season at Rockhampton and $\mathbf{b}$ all locations in July. Vertical bars show the standard errors.

Table 2. Range (minimum-maximum) in seasonal percentage survival of Hendra virus (24 h after environmental exposure) at six locations for the period 1993-2012.

\begin{tabular}{lllll}
\hline & Summer-January & Autumn-April & Winter-July & Spring-October \\
\hline Cairns & $23.5(5.0-28.5)$ & $22.1(8.3-30.4)$ & $41.1(16.6-59.7)$ & $23.8(15.2-39.0)$ \\
Townsville & $26.2(6.6-32.8)$ & $26.2(10.1-36.3)$ & $42.2(23.8-66.0)$ & $30.9(11.0-41.9)$ \\
Mackay & $27.6(8.1-35.7)$ & $29.7(13.3-43.0)$ & $45.5(32.9-78.4)$ & $21.2(14.5-35.7)$ \\
Rockhampton & $31.4(8.3-39.7)$ & $36.2(4.1-40.3)$ & $44.9(31.4-76.3)$ & $44.4(8.5-52.9)$ \\
Murwillumbah & $41.3(13.5-54.8)$ & $27.1(21.6-48.7)$ & $40.3(48.6-88.9)$ & $54.6(13.6-68.2)$ \\
Kempsey & $50.8(10.3-61.1)$ & $31.3(30.2-61.5)$ & $29.7(52.9-82.6)$ & $41.6(29.8-71.4)$ \\
\hline
\end{tabular}

between maximum and minimum survival after $24 \mathrm{~h}$. The single widest variation was for Murwillumbah in October with a range of $54.6 \%$.

In all circumstances, the longer the period of environmental exposure, the lower is the survival. However, considerable differences in virus survival due to time of excretion within a 12-h period occur with the greatest difference being between July (highest survival; modest variation between excretion times) and January (lowest overall survival; highest variation due to time of excretion) (Fig. 6). The lowest survival simulated was $36 \%$ being for the hottest period (January) and the longest post-excretion period (18 h; 6 p.m.).

Actual temperature varies at a particular point within a location due to factors such as shade, air flow and other microclimatic factors. Figure 7 shows the simulated effect of a reduction in maximum temperatures of up to $5^{\circ} \mathrm{C}$ for each season in Rockhampton. A $5^{\circ} \mathrm{C}$ reduction in maximum temperature gives rise to about a $10 \%$ increase in $\mathrm{HeV}$ survival after $24 \mathrm{~h}$ during all seasons of the year. The seasonal difference in virus survival is again evident. 


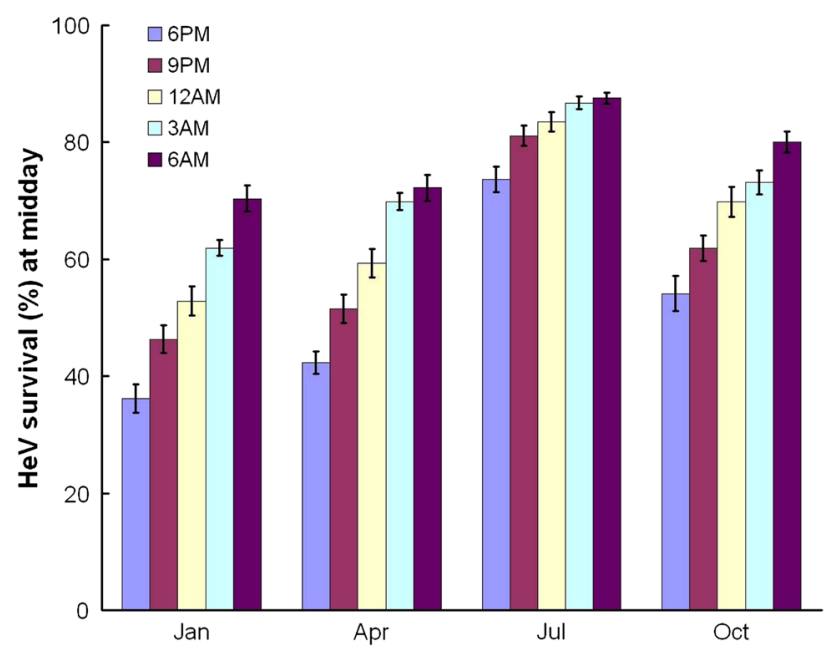

Figure 6. The effect of timing of excretion of virus on survival of Hendra virus in urine to midday for five excretion times at Rockhampton for all seasons at Rockhampton (vertical bars show standard errors when actual temperatures for 1993-2012 are used).

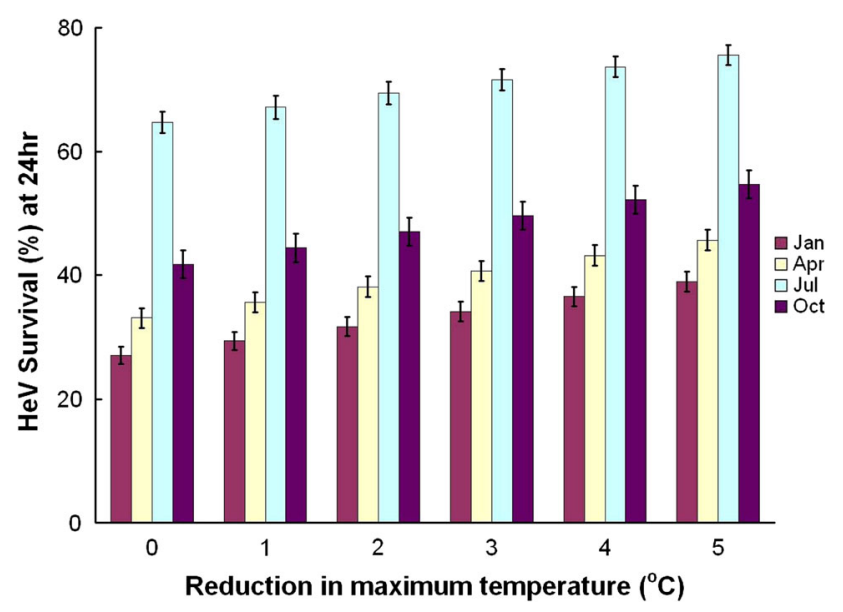

Figure 7. The survival of Hendra virus at $24 \mathrm{~h}$ after excretion at Rockhampton during summer and winter as influenced by a reduction in maximum temperature of up to $5^{\circ} \mathrm{C}$. Vertical bars standard errors when actual temperatures for 1993-2012 are used.

The monthly pattern of $\mathrm{HeV}$ survival in the environment at $24 \mathrm{~h}$ after excretion (Fig. 8b) follows the general cumulative monthly occurrence of equine $\mathrm{HeV}$ cases reported in eastern Australia (Fig. 8a). One apparent anomaly is the absence of reported equine cases during March and April, when simulated survival during this period is very similar to that during the October-December period. The other notable feature is that the peak in cases during June-July-August is more pronounced than the increase in survival of $\mathrm{HeV}$ at this time of year.
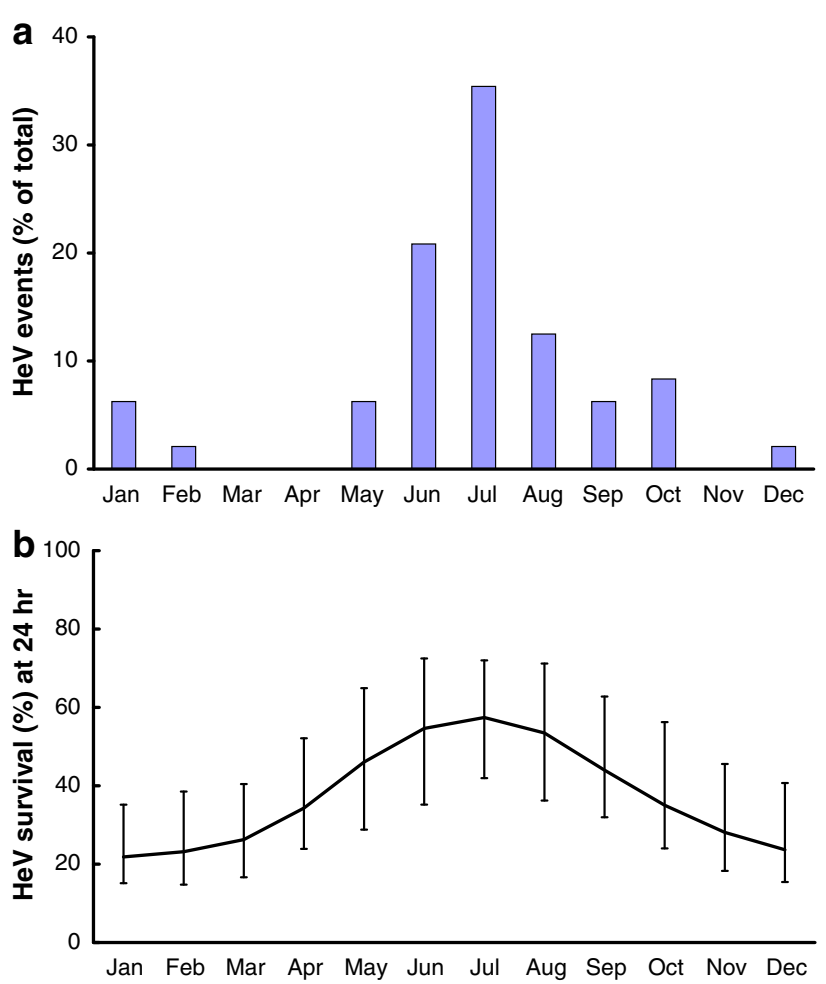

Figure 8. a The cumulative annual pattern of Hendra virus equine cases in Australia and $\mathbf{b}$ the annual pattern of Hendra virus survival at $24 \mathrm{~h}$ after excretion. Vertical bars show the range of simulated values using mean monthly temperatures for the six locations.

There were no significant differences between mean survival for the same months in case years and non-case years (data not shown).

\section{Discussion}

$\mathrm{HeV}$ infection in horses likely has a complex causality, as typically do most emerging infectious diseases of wildlife origin (Daszak et al. 2000; Dobson and Foufopoulos 2001; Li et al. 2005). Yet few papers to date have explored potential environmental drivers for $\mathrm{HeV}$ emergence (Fogarty et al. 2008; McFarlane et al. 2011). In this study, we used a simulation modelling approach to demonstrate the influence of temperature on $\mathrm{HeV}$ survival in the environment.

We initially explored virus survival at six $\mathrm{HeV}$ incident locations along a 1,750-km latitudinal gradient from Cairns $\left(16^{\circ} 60^{\prime} \mathrm{S}\right)$ in far north Queensland to Kempsey $\left(32^{\circ} 05^{\prime} \mathrm{S}\right)$ in central New South Wales using actual temperatures for the first 4 days of the mid-month in each season over the last 20 years (Fig. 4). While (for logistical purposes) we limited this study to detailed consideration of six locations, all 
reported incident locations are effectively within this gradient, thus our findings have broad relevance. The identified between-location trend of increasing virus survival from north to south was not unexpected, given the decreasing mean temperature gradient. Similarly, the seasonal association with virus survival was not unexpected, reflecting the within-year temperature profile. However, the magnitude of within-location temperature variability (and subsequent differences in survival-Table 2) over the 20-year period was quite large and may offer a fundamental insight into the spatially sporadic nature of equine $\mathrm{HeV}$ cases. Temperatures conducive to substantial $\mathrm{HeV}$ survival can occur in any of the locations used in this study and in many/most months of the year.

The city of Rockhampton in central Queensland was the focus of two recent $\mathrm{HeV}$ incidents, the first in late May 2012 and the second in mid-July 2012. We used data from the Rockhampton weather station to examine the effect of a number of biologically plausible temperature scenarios on the survival of $\mathrm{HeV}$. The findings reiterate the expected longer virus survival in winter, but also reveal that even in mid-summer, survival may be high in particular years (Table 2). Thus, temperature variability could contribute to the explanation of the occasional occurrence of equine cases outside the predominant Australian winter temporal clustering.

When we examined the effect of the time of virus excretion during the night on survivability at midday, we found (as expected) that virus excreted $18 \mathrm{~h}$ earlier had a lower survival than virus excreted $12 \mathrm{~h}$ earlier, which in turn had a lower survival than virus excreted just 6 or $9 \mathrm{~h}$ earlier (Fig. 6). However, the difference is surprisingly modest and less than the variation in survival between years for excretion at a single timepoint. This simulation was prompted by a common horse-owner query regarding a 'safe' time to return horses to a paddock where flying-foxes were active overnight. Our findings preclude a definitive answer to this question on the basis of temperature alone. Clearly, exposure risk decreases with temperature over time, but other environmental factors also influence risk. $\mathrm{HeV}$ is very sensitive to desiccation (Fogarty et al. 2008). Multiple environmental factors contribute to desiccation (rainfall, humidity, UV index, microclimate) and undoubtedly influence $\mathrm{HeV}$ survival in the environment as well, but a lack of empirical data precluded their inclusion in our parsimonious model. In addition to environmental factors, ecological (Plowright et al. 2008) and husbandry factors (Kung et al. 2013) may also influence exposure risk.
At a practical level, the recommendations of Biosecurity Queensland (http://www.daff.qld.gov.au/animal-industries/ animal-health-and-diseases/a-z-list/hendra-virus/general-in formation/reducing-the-risk-for-horses, accessed 5 August 2013) include excluding horses from paddocks where flying-foxes are active, and covering horse feed and water points. These provide overarching risk mitigation strategies.

In examining the potential significance of microclimate on virus survival, we found a trend of increased survival in a cooler microclimate. However, a $5^{\circ} \mathrm{C}$ temperature differential compared to ambient temperature, increased virus survival by less than the previously identified year-to-year variation. We included this simulation because, at a property or paddock level, there can be substantial differences in average temperatures between areas of woody vegetation and open grassland, and specifically between canopied areas and open patches of woodlands and forests common throughout coastal and sub-coastal areas of Queensland and New South Wales (DuPont 1997; Scanlan 2002).

There is higher survival of virus in mango pulp than in urine (Fogarty et al. 2008). Although there were insufficient data (Fogarty et al. 2008) to develop a sound model on this aspect, preliminary modelling by one of the authors (JCS) suggested that the difference in survival is likely to be less than the variation between years for the respective media. If $\mathrm{HeV}$ survival in an organic medium (fruit debris, spats, faeces) is greater than in urine, and if these organic media also buffer virus from desiccation [another environmental factor influencing virus survival in experimental studies (Fogarty et al. 2008)], then such material further prolongs virus survival. This rationale ratifies recommended risk management strategies to remove horse food and water points from underneath trees, to cover horse feed and water points, and to exclude horses from grazing underneath trees in which flying-foxes are feeding.

Our penultimate analysis looked at the within-year pattern of virus survival compared with the cumulative within-year pattern of equine $\mathrm{HeV}$ cases (Fig. 8). The former closely reflects the latter, indicating a strong correlation between lower temperature and infection risk. Such a correlation is biologically plausible, given that lower temperatures extend virus survival time, which in turn increases the 'window of opportunity' of effective exposure for a horse. While the findings of Fogarty et al. (2008) suggested such an association, their experimental study was limited to two temperature points. Our model is based on 
additional data using real temperature data from real case locations, adding support to that putative association. The absence of reported cases to date in the (Australian) autumn months of March and April, when the temperature profile is similar to that of spring months (in which cases have been reported) can plausibly be explained either by chance, or by the additional negative influence of other seasonal factors on virus survival. The occurrence of the first reported February case in 2013 supports the former, and the likelihood is that cases will eventually be reported in all months. The more pronounced peak of cases June to August is consistent with the presence of additional risk factors at this time, or alternatively may reflect the unprecedented mid-year cluster of cases in 2011.

Finally, we sought to explore whether reported $\mathrm{HeV}$ case years had a different temperature profile to non-case years. We found no consistent difference between case years and non-case years suggesting that, while temperature may be an important factor in virus survival, other factors are needed to constitute sufficient cause for effective transmission to horses. This putative complex causality has been previously discussed (Field et al. 2011) in seeking an association between virus excretion prevalence in flyingfoxes and equine cases. They suggest that sufficient cause (in addition to the presence of virus) may include unidentified host, agent and environmental factors.

Although there are limited experimental studies on the survival of $\mathrm{HeV}$, a significant body of work exists on the survival and/or inactivation of influenza viruses (Casanova et al. 2010) and coronaviruses (Weber and Stilianakis 2008), indicating that the survival of enveloped viruses in general is dependent on temperature and relative humidity. Consistent with our contention regarding $\mathrm{HeV}$, some of this work also suggests a role for additional factors such as ultraviolet radiation (Weber and Stilianakis 2008).

In this paper, we have focused solely on elaborating the effects of temperature on virus survival, and the findings should be interpreted in this context. The intent was not to illustrate actual survivability, but rather relative survivability and thus relative exposure and infection risk for horses. Figure 5 indicates that theoretically, up to $30 \%$ of virus may remain in the environment after 4 days. This projection reflects the effect of temperature in isolation; actual survivability will be much shorter, because actual survivability will reflect the effect of a range of factors in addition to temperature. As discussed earlier, desiccation, $\mathrm{pH}$ and substrate are additional factors known to influence virus survival in laboratory studies (Fogarty et al. 2008). In an environmental context, climate factors such as humidity, rainfall, wind and ultraviolet radiation intensity will undoubtedly contribute to actual $\mathrm{HeV}$ survival. There may well be additional, as yet unidentified, factors.

\section{CONCLUSIONS}

We have sought to extrapolate the findings of experimental studies on $\mathrm{HeV}$ survival in the laboratory to the real world, using Australian Bureau of Meteorology data from known equine $\mathrm{HeV}$ case locations. Our simulation modelling shows, first, that virus survival varies with location and with season, and second, that factors such as the timing of virus excretion during the night and microclimate account for less variation in virus survival than does temperature variation between years. Finally, and importantly, the model shows that the effect of ambient temperature on the survival of virus in the environment mirrors both the annual clustering of $\mathrm{HeV}$ cases in the Australian winter, and occasional sporadic cases at other times of year. We do not contend that temperature is the sole or primary driver for infection in horses, nor that temperature alone influences virus survival in the environment, but rather that it constitutes part of a 'sufficient cause' paradigm, as previously proposed (Field et al. 2011). Further work is required to elaborate other contributing causal components.

\section{ACKNOWLEDGMENTS}

The authors gratefully acknowledge the members of the Queensland Centre for Emerging Infectious Diseases team and the special funding from the Queensland Government.

\section{REFERENCES}

Baldock FC, Douglas IC, Halpin K, Field H, Young PL, Black PF (1996) Epidemiological investigations into the 1994 equine morbillivirus outbreaks in Queensland, Australia. Sing Veterinary Journal 20:57-61

Casanova LM, Jeon S, Rutala WA, Weber DJ, Sobsey MD (2010) Effects of air temperature and relative humidity on coronavirus survival on surfaces. Applied Environmental Microbiology 76:2712-2717

Daszak P, Cunningham AA, Hyatt AD (2000) Emerging infectious diseases of wildlife-threats to biodiversity and human health. Science 287:443-449

Dobson A, Foufopoulos J (2001) Emerging infectious pathogens of wildlife. Philosophical Transactions of the Royal Society London B Biological Sciences 356:1001-1012 
Dupont GV (1997) The Effects of Trees on Microclimate Along a Rainfall Gradient in South-Queensland. MSc Thesis, University of Queensland, Brisbane, p 244

Field H (2005) The Ecology of Hendra Virus and Australian Bat Lyssavirus. PhD thesis, The University of Queensland, Brisbane, Australia. http://www.hendravirus.org/Documents/Hume\% 20Field\%20Field\%20Thesis\%202004.pdf. Accessed 31 Nov 2013

Field HE, Barratt PC, Hughes RJ, Shield J, Sullivan ND (2000) A fatal case of Hendra virus infection in a horse in north Queensland: clinical and epidemiological features. Australian Veterinary Journal 78:279-280

Field H, Schaaf K, Kung N, Simon C, Waltisbuhl D, Hobert H, Moore F, Middleton D, Crook A, Smith G, Daniels P, Glanville R, Lovell D (2010) Hendra virus outbreak with novel clinical features, Australia. Emerging Infectious Diseases 16:338-340

Field H, de Jong C, Melville D, Smith C, Smith I, Broos A, Kung YH, McLaughlin A, Zedderman A (2011) Hendra virus infection dynamics in Australian fruit bats. PLoS ONE 6:e28678

Fogarty R, Halpin K, Hyatt AD, Daszak P, Mungall BA (2008) Henipavirus susceptibility to environmental variables. Virus Research 132:140-144

Halpin K, Young PL, Field HE, Mackenzie JS (2000) Isolation of Hendra virus from pteropid bats: a natural reservoir of Hendra virus. Journal of General Virology 81:1927-1932

Kung N, McLaughlin A, Taylor M, Moloney B, Wright T, Field H (2013) Hendra virus and horse owners-risk perception and management. PLoS ONE 8(11):e80897. doi:10.1371/journal. pone.0080897

Li W, Shi Z, Yu M, Ren W, Smith C, Epstein JH, Wang H, Crameri G, Hu Z, Zhang H, Zhang J, McEachern J, Field H,
Daszak P, Eaton BT, Zhang S, Wang L-F (2005) Bats are natural reservoirs of SARS-like coronaviruses. Science 310:676-679

McFarlane R, Becker N, Field H (2011) Investigation of the climatic and environmental context of Hendra virus spillover events 1994-2010. PLoS ONE 6:e28374

Murray K, Rogers R, Selvey L, Selleck P, Hyatt A, Gould A, Gleeson L, Hooper P, Westbury H (1995) A novel Morbillivirus pneumonia of horses and its transmission to humans. Emerging Infectious Diseases 1:31-33

Playford EG, McCall B, Smith G, Slinko V, Allen G, Smith I, Moore F, Taylor C, Kung YH, Field H (2010) Human Hendra virus encephalitis associated with equine outbreak, Australia, 2008. Emerging Infectious Diseases 16:219-223

Plowright RK, Field HE, Smith C, Divljan A, Palmer C, Tabor G, Daszak P, Foley JE (2008) Reproductive and nutritional stress are risk factors for Hendra virus infection in little red flying foxes (Pteropus scapulatus). Proceedings of the Royal Society Biological Sciences 275(1636):861-869

Reed LJ, Muench H (1938) A simple method for estimating fifty percent end points. American Journal of Hygiene 27:493-497

Scanlan JC (2002) Some aspects of tree-grass dynamics in Queensland's grazing lands. Rangeland Journal 24:56-82

Selvey LA, Wells RM, McCormack JG, Ansford AJ, Murray K, Rogers RJ, Lavercombe PS, Selleck P, Sheridan JW (1995) Infection of humans and horses by a newly described morbillivirus. The Medical Journal of Australia 162:642-645

Weber TP, Stilianakis NI (2008) Inactivation of influenza A viruses in the environment and modes of transmission: a critical review. Journal of Infection 57:361-373 